\title{
Challenges and Opportunities of Nutritional Kitchen Garden under Changing Climate Scenario of Koderma, Jharkhand, India
}

\author{
Chanchila Kumari $^{1 *}$, Binit Kumar ${ }^{1}$, Manish Kumar ${ }^{1}$ and V.K. Singh ${ }^{2}$ \\ ${ }^{1}$ Krishi Vigyan Kendra, Koderma, ICAR-NRRI-CRURRS, (Jharkhand)-825109, India \\ ${ }^{2}$ IISR, Lucknow (Uttar Pradesh)-226002, India \\ *Corresponding author
}

\begin{tabular}{|l|}
\hline Ke y w o r d s \\
Drought, Vegetable \\
production, \\
Climatic condition \\
\hline Article Info \\
\hline $\begin{array}{l}\text { Accepted: } \\
10 \text { April } 2018 \\
\text { Available Online: } \\
10 \text { May } 2018\end{array}$ \\
\hline
\end{tabular}

\section{A B S T R A C T}

The vegetable growers of Jharkhand state are challenged with growing abundant, hygienic and nutritious food for an increasing population in the face of changing climate and pest pressures. The Jharkhand state has endowed with quite a diverse climatic condition, hashed, erratic or withdrawal rainfall, drought prone, and unavailability of irrigation. Scarcities of healthy vegetable directly affect the nutritious daily meal. Iron deficiency, anemia is quite wide spread in rural area of Jharkhand, the prevalence varying from 36.5 per cent in adult males to 65 per cent or more in women and children. There is an urgent need for providing health food security to our population by supplying nutrition balanced diet. Vegetables are rich source of vitamins, minerals, and proteins with increased health awareness in the general public and changing dietary patterns, vegetables are now becoming an integral part of average household's daily meals. Protected cultivation of vegetables, including the water saving methods like polythene and straw mulching gave significant increment in production of seasonal as well as off season vegetable crops. A single method to overcome the effects of environmental stresses on vegetables will be achieve through systematic approaches, where all available options are considered in an integrated manner, will be the most effective and ultimately the most sustainable, particularly for drought prone area under a variable climate.

\section{Introduction}

The adventitious effect of vegetables in providing balanced diet and nutritional food security has been recognized by the world. Vegetables are now considered as health food and play important role in overcoming micronutrient deficiencies including provides opportunities of higher farm income. The worldwide production of vegetables has tremendously gone up during the last two decades and the value of global trade in vegetables now exceeds that of cereals. Hence, more emphasis is being given in the developing countries like India to promote cultivation of vegetables. India ranks first in peas and cauliflower production and is the second largest producer of onion, brinjal and cabbage. In spite of all these achievements, per capita consumption of vegetables in India is very low against WHO standards (180 g/day/capita against 300 g/day capita recommended by FAO). Development of hybrid varieties, integrated insect-pest and 
diseases management practices, integrated nutrient management and standardizing improved agro techniques including organic farming have changed the scenario of vegetables production in the country. In short, productivity, quality and post-harvest management of vegetables will have to be improved to remain competitive in the next decades. The major objectives of reducing malnutrition and alleviating poverty in developing countries through improved production and consumption of safe vegetables will involve adaptation of current vegetable systems to the potential impact of climate change (Unger, 1991). Genetic populations are being developed to introgression and identify genes conferring tolerance to stresses and at the same time generate tools for gene isolation, characterization and genetic engineering.

Furthermore, agronomic practices that conserve water and protect vegetable crops from sub-optimal environmental conditions must be continuously enhanced and made easily accessible to farmers in the developing world. Current, and new, technologies being developed through plant stress physiology research can potentially contribute to mitigate threats from climate change on vegetable production. However, farmers in developing countries are usually small-holders, have fewer options and must rely heavily on available resources. Thus, technologies that are simple, affordable, and accessible must be used to increase the resilience of farms in less developed countries.

Adverse environmental condition gave significant crop losses worldwide, especially in drought prone area, reducing average yields for most major crops by more than 50\% (Mangal and Singh, 1993). Climatic changes (high temperature, salinity, drought, less rainfall) will influence the severity of environmental stress imposed on vegetable crops. Extreme climatic conditions will also impose bad impact in soil fertility and increase soil erosion. Thus, additional fertilizer application or improved nutrient-use efficiency of crops will be needed to maintain productivity. The response of plants to environmental stresses depends on the plant developmental stage, length and severity of the stress. Environmental interactions may make the stress response of plants more complex or influence the degree of impact of climate change. Due to this the biochemical, morphological and in advance stage some genetic modifications may occurs in plant to survive (Mishra et al., 2010).

High population growth rate has also given rise to high demand in basic dietary vegetables. Increased health awareness, high population growth rate, changing dietary patterns of increasingly affluent middle class and availability of packaged vegetables, has therefore generated a year round high demand for vegetables in the country in general and in major city centers in particular. However, our farmers have yet not been able to in cash this opportunity and still follow traditional sowing and picking patterns. This results in highly volatile vegetable supply market wherein the market is flooded with seasonal vegetables irrespective of demand presence on one hand and very high priced vegetables in off-season on the other. Lack of developed vegetable processing and storage facility robs our farmers from their due share of profit margins (Chandra et al., 2000). In natural season local vegetables flood the markets substantially bringing down the prices. In the absence of storage infrastructure and vegetable processing industry in the country, off-season vegetables farming is the only viable option that can add value to the farmer produce. The facility of growing off-season vegetables also allows for growing non-conventional varieties of vegetables, which are in high demand in the market. Vegetables can be cultivated in off- 
season, with the induction of an artificial technique like greenhouse technology, in which temperature and moisture is controlled for specific growth of vegetables (Singh and Dhaulakhandi, 1998). The production of vegetables all around the year enables the growers to fully utilize their resources and supplement income from vegetable growing as compared to other normal agricultural crops. Hybrid seeds that provide higher yield can lead to lower unit cost. Higher prices can be obtained by producing the right crops, at the right times and of better quality. They may also depend on negotiating skills and targeting high price buyers. Since, the land holding of farmers is decreasing, there is a need to increase the productivity of available land, and off-season vegetable farming is a measure through which we can attain higher profit margins from the crop.
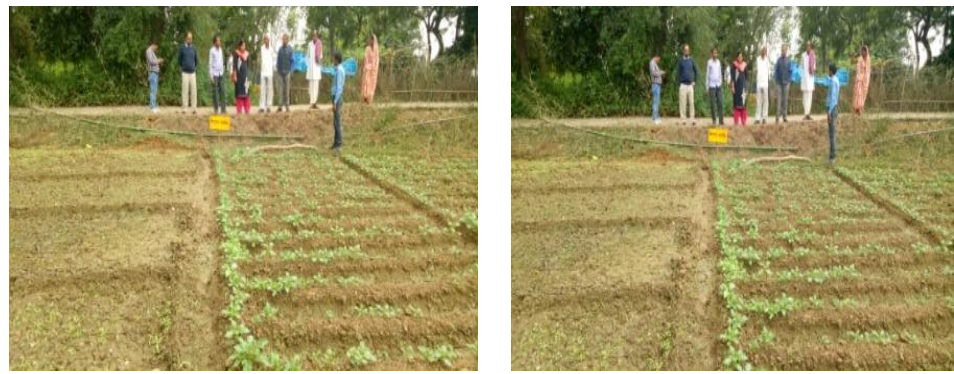

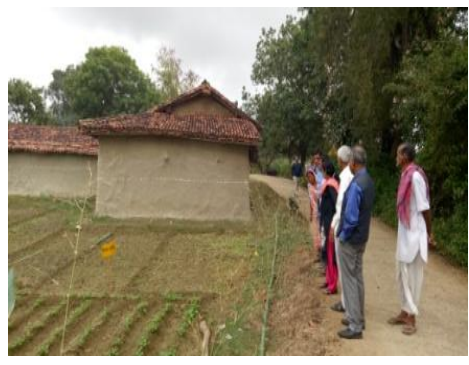

Various management practices have the potential to raise the yield of vegetables grown under hot/wet conditions of the low/ medium/ up land tropics. Strategies include modifying fertilizer application to enhance nutrient availability to plants, direct delivery of water to roots likewise there are several methods of applying irrigation water and the choice depends on the crop, water supply, soil characteristics and topography (Sonawane et al., 2008). Application of irrigation water could be through overhead, surface, drip, or sub-irrigation systems. Surface irrigation methods are utilized in more than $80 \%$ of the world's irrigated lands yet its field level application efficiency is often $40-50 \%$, minimize the water loss by polythene mulching, production of vegetables on small scale, grafting to increase flood and disease tolerance, and use of soil amendments to improve soil fertility and enhance nutrient uptake by plants. It is unlikely that a single method to overcome the effects of environmental stresses on vegetables will be found. Systematic approaches, where all available options are considered in an integrated manner, will be the most effective and ultimately the most sustainable, particularly for tropical area under a variable climate.

Upland areas in Jharkhand are reasonably populated with local tribes and troops. Vegetable production for them during winter and summer months when environment mainly temperature is unfavorable for their growth, has been discussed. Protected production technologies or green house technologies developed for these areas such as use of local poly house, both underground and above ground along with combination of both. Production of leafy vegetables under harsh atmosphere, cucurbits and almost all vegetables in drought prone area by using protected agriculture technology.

The conservation agriculture helps reduce or rather reverse the natural resource degradation by improving soil health and reducing ground water and environmental pollution. The soil moisture conservation and soil temperature moderation can help to a large extent in overcoming the adverse effects of climate change. 


\section{References}

Chandra P., P.S. Sirohi, T.K. Behera and A.K. Singh (2000). Cultivating vegetables in polyhouse. Indian Horticulture (45): $17-$ 25.

Lane1, A. and Jarvis, A (2006). Changes in Climate will modify the Geography of Crop Suitability: Agricultural Biodiversity can help with Adaptation. An Open Access Journal published by ICRISAT http:// Journal Special Project/ sp2.pdf.

Mangal J.L. and G.R. Singh (1993). Offseason vegetable production. In: Adv. In Horticulture (6.2): 673-685.

Mishra, G. P., Singh, N. and Kumar, H. and Singh, S. B. (2010). Protected Cultivation for Food and Nutritional
Security at Ladakh Defence Science Journal (61.2): 219-225.

Singh, B. and Dhaulakhandi, A. B. (1998). Application of solar greenhouse for vegetable production in cold desert in renewable energy. Energy Efficiency Policy and the Environment. Elsevier Science Ltd, UK: 2511-314.

Sonawane, Y.R., Khandekar, S., Mishra, B.K. and Soundra Pandian, K. K. (2008). Environment Monitoring and Control of a Polyhouse Farm through Internet. World Bank: India Country Overview: 1-6.

Unger PW (1991). Organic matter, nutrient and $\mathrm{pH}$ distribution in no- and conventional- tillage semiarid soils. Agronomy Journal (83): 186-189.

\section{How to cite this article:}

Chanchila Kumari, Binit Kumar, Manish Kumar and Singh, V.K. 2018. Challenges and Opportunities of Nutritional Kitchen Garden under Changing Climate Scenario of Koderma, Jharkhand. Int.J.Curr.Microbiol.App.Sci. 7(05): 1084-1087. doi: https://doi.org/10.20546/ijcmas.2018.705.132 